\title{
PENERAPAN MODEL PEMBELAJARAN CONTEXTUAL TEACHING AND LEARNING DENGAN MENGGUNAKAN MEDIA MODUL DALAM MENINGKATKAN HASIL BELAJAR MATA PELAJARAN AKUNTANSI PADA SISWA SMA SE-KOTA BANDUNG
}

\author{
Imas Purnamasari \\ Heraeni Tanuatmodjo \\ Leni Yuliyanti \\ Universitas Pendidikan Indonesia
}

\begin{abstract}
The results of student learning is a combination of various factors that affect the overall learning process. The phenomenon in this study is the lack of student learning outcomes are seen from the results of the national exam on economic subjects, especially the material accounting, one of the causes of the problems in the learning process, namely on how to give lessons conducted by teachers, and the use of instructional media, especially the media module.

This study, use the method of the experiment to make a difference between the results of the study on the student teaching and learning by contextual the use of the media, the students are not using the models of the contextual teaching and learning to use media. Results of the analysis of 10 schools in the city of bandung at 8 school with the influence of contextual teaching and learning module, using this hypothesis can be seen from the increase is the result of study to students.
\end{abstract}

Keys word: Model Contextual Teaching and learning, learning outcomes

\section{PENDAHULUAN}

Pendidikan diarahkan untuk mengembangkan sumber daya yang berkualitas. Produk atau output yang di hasilkan berupa lulusan yang memiliki kemampuan melaksanakan perannya di masa yang akan datang. Untuk kehidupan yang lebih baik, buat dirinya dan bangsanya. Berhasil tidaknya tujuan pendidikan banyak tergantung pada proses pembelajaran yang dilaksanakan.

Dalam proses pembelajaran harus tercipta proses komunikasi transaksional yang bersifat timbal balik, baik antara guru dengan siswa maupun siswa dengan siswa untuk mencapai tujuan pembelajaran yang telah ditetapkan secara efektif. Siswa sebagai peserta didik diperlakukan sebagai subjek utama dalam proses pembelajaran di sekolah, dan guru menempati posisi yang cukup sentral dan strategis untuk menciptakan suasana belajar yang kondusif dan menyenangkan, sehingga dapat dengan mudah mengarahkan siswa untuk mencapai tujuan pembelajaran secara optimal.

Dalam rangka mewujudkan pendidikan yang bermutu sesuai dengan tujuan pendidikan, telah dilakukan berbagai upaya diantaranya melalui standar nilai kelulusan, perbaikan pada kurikulum pendidikan, peningkatan kualitas guru, peningkatan sarana kependidikan baik itu berupa penyediaan gedung maupun buku-buku dan alat peraga.

Mengenai perbaikan mutu pendidikan di Indonesia maka dibuat standar kelulusan, telah dilakukan sejak tahun ajaran 2002/2003 dengan standar nilai kelulusan UAN 3,01. Namun ironisnya dengan standar nilai kelulusan Ujian 
Akhir Nasional (UAN) yang sekarang menjadi Ujian Nasional (UN) yang sangat rendah tersebut masih banyak siswa yang tidak lulus. Pada tahun selanjutnya yaitu tahun 2003/2004 standar nilai kelulusan pun dinaikkan menjadi 4,01 dengan harapan mutu pendidikan di Indonesia lebih meningkat. Namun seperti halnya standar tahun 2002/2003 standar 4,01 pun sebenarnya masih sangat rendah namun masih banyak siswa yang tidak lulus dari standar nilai kelulusan ini. Standar nilai kelulusan kembali ditingkatkan lagi menjadi 4,25 pada tahun 2004/2005 namun lagi-lagi banyak siswa yang tidak lulus. Pada tahun ajaran 2005/2006 standar nilai kelulusan naik menjadi 4,50. Untuk tahun 2006/2007 standar nilai kelulusannya menjadi 5,00, dan untuk UN tahun 2007/2008 standar nilai kelulusan menjadi 5,25. Pada tahin ajaran 2008/2009 standar kelulusan dinaikan lagi menjadi 5,50 sampai tahun ajaran 2012/2013 pun standarnya masih sama memiliki nilai rata-rata minimal 5,50 untuk seluruh mata pelajaran yang diujikan.

Melihat kebijakan yang selalu berubah-rubah tentunya dengan harapan adanya peningkatan kualitas pendidikan, namun dilapangan masih saja banyak siswa yang belum mencapai Standar kelulusan pada materi ujian nasional. Berdasarkan hasil tim survey dari Universitas Pendidikan Indonesia Tahun 2011, khususnya di Sekolah menengah Atas pada mata pelajaran ekonomi masih banyak standar kelulusan yang belum tercapai. Ketika ditelusuri ternyata pada materi akuntansinya yang banyak tidak mencapai standar kelulusan.

Pada bulan September samapi November tahun 2012 dilakukan survey lapangan ke Sekolah Menengah Atas Negeri Se Jawa barat, dengan memberikan pre test soal-soal Ujian Nasional Ekonomi khususnya Materi Akuntansi, maka di dapat data sebagai berikut:

\section{Tabel 1}

Daftar Rekapitulasi Rata-Rata Pre Test Siswa Pada Soal-soal Ujian Nasional Materi Akuntansi Di Jawa Barat Tahun 2012

\begin{tabular}{lccccc} 
Nama Sekolah & $\begin{array}{c}\text { Jumlah } \\
\text { Nilai } \\
\text { Siswa } \\
\text { di Bawah } \\
\text { SKL }\end{array}$ & $\begin{array}{c}\text { Jumlah } \\
\text { Nilai } \\
\text { Siswa } \\
\text { di Atas } \\
\text { SKL }\end{array}$ & $\begin{array}{c}\text { Jumlah } \\
\text { Siswa }\end{array}$ & $\begin{array}{c}\text { Rata- } \\
\text { Rata Nilai } \\
\text { Pre Test }\end{array}$ & $\begin{array}{c}\text { Persentase } \\
\text { \% }\end{array}$ \\
\hline SMKN 18 Bandung & 13 & 28 & 41 & & \\
\hline SMKN 5 Sukabumi & 17 & 16 & 33 & 5,26 & 68,29 \\
\hline SMKN 1 Cilaku & 14 & 25 & 39 & 5,00 & 64,48 \\
\hline SMAN 1 Kalijati & 17 & 5 & 22 & 3,55 & 9,09 \\
\hline SMAN 1 Rancakalong & 16 & 1 & 17 & 2,72 & 5,88 \\
\hline
\end{tabular}

Kurangnya pencapaian Standar Kelulusan dari hasil observasi diduga siswa tidak bisa mengerjakan soal-soal ujian nasional yang bentuk soalnya kontektual. Dalam proses pembelajaran guru hanya memberikan soal berbentuk narasi sedangkan dalam soal ujian nasional terdapat soal-soal yang langsung mengambil dari bukti transaksi sesuai dengan kenyataannya dilapangan. Masih besarnya angka ketidak tercapaian standar kelulusan jika dibiarkan maka daya 
saing anak didik akan semakin tertinggal, setelah lulus akan terjadinya pengangguran karena daya saing yang rendah.

Upaya peningkatan mutu pendidikan di Indonesia, khususnya mengenai hasil pembelajaran sangat perlu untuk diperhatikan. Untuk meningkatkan mutu pendidikan di lihat dari outputnya, maka harus memperbaiki dari prosesnya terlebih dahulu. Untuk dapat meningkatkan hasil belajar maka harus terlebih dahulu mengetahui mengenai faktor yang mempengaruhi hasil belajar siswa. Telah banyak yang mengemukakan beberapa faktor yang mempengaruhi hasil belajar siswa. Faktor tersebut diantaranya yaitu: pengetahuan guru, kegiatan belajar mengajar, metode yang digunakan oleh guru, media yang digunakan, sumber belajar, kurikulum, minat siswa terhadap pelajaran, keadaan emosi siswa dan lain sebagainya. Seperti yang diungkapkan oleh Sadirman (2008:4):

"Bahwa yang mempengaruhi prestasi belajar siswa ada dua faktor, faktor internal dan faktor eksternal. Faktor internal terdiri dari keadaan fisik siswa, intelegensi siswa, serta keadaan psikologi siswa misalnya minat dan juga motivasi. Sedangkan yang termasuk dalam faktor eksternal adalah kemampuan mengajar guru, media pembelajaran yang digunakan guru, metode yang digunakan, sumber atau bahan pelajaran, serta kurikulum."

Begitu pula seperti yang diungkapkan Slameto (2003:35) "Bahwa yang dapat mempengaruhi hasil belajar siswa adalah metode mengajar guru, materi pelajaran yang diberikan guru, media pengajaran yang digunakan, serta penilaian".

Proses pembelajaran dapat lebih dinamis dan akan mencapai sasaran yang diinginkan jika menerapkan model pembelajaran yang dapat mengaktifkan siswa seperti model pembelajaran contextual teaching and learning, model cooperatif learning, dan ditambahkan juga alat bantu atau media lain, seperti media modul, media proyeksi, media audio, media tiga dimensi dan sebagainya.

Berdasarkan fenomena di atas maka peneliti mengajukan penelitian dengan membatasi cakupan daerah penelitian diutamakan dikota bandung, sehingga judul yang diusulkan yaitul: "Penerapan model pembelajaran Contextual Teaching And Learning Dengan Menggunakan Media Modul Dalam Meningkatkan Hasil Belajar Mata Pelajaran Akuntansi Pada Siswa SMA Se-Kota Bandung”.

\section{KAJIAN PUSTAKA DAN KERANGKA PEMIKIRAN \\ Kajian pustaka \\ Faktor-Faktor yang Mempengaruhi Hasil Belajar}

Untuk mencapai hasil belajar yang memuaskan maka perlu diperhatikan beberapa faktor yang mempengaruhi hasil belajar.Secara umum hasil belajar dipengaruhi oleh faktor internal dan faktor eksternal.Faktor internal adalah faktor yang berasal dari dalam diri siswa sedangkan faktor eksternal adalah faktor yang berasal dari luar diri siswa. Faktor-faktor yang mempengaruhi hasil belajar menurut Djamarah (2002:143) adalah sebagai berikut :

1. Faktor eksternal (luar), yaitu :

a. Lingkungan, terdiri dari lingkungan alam dan lingkungan sosial.

b. Instrumental, terdiri dari kurikulum, program, metode, media, sarana dan fasilitas, serta guru. 
2. Faktor internal (dalam), yaitu :

a. Fisiologis, terdiri dari kondisi fisik dan panca indera.

b. Psikologis, antara lain bakat, minat, kecerdasa, motivasi, dan kemampuan kognitif, disiplin dan partisipasi

Sejalan dengan pendapat Syah (2006:144) mengemukakan bahwa "faktorfaktor yang mempengaruhi hasil siswa terdiri dari dua faktor yaitu faktor yang datangnya dari individu siswa (internal factor), dan faktor yang datang dari luar diri individu siswa (eksternal factor)". Keduanya dapat dijelaskan sebagai berikut:

1. Faktor internal anak, meliputi:

a. Faktor psikis (jasmani). Kondisi umum jasmani yang menandai dapat mempengaruhi semangat dan intensitas anak dalam mengikuti pelajaran.

b. Faktor psikologis (kejiwaan). Faktor yang termasuk aspek psikologis yang dapat mempengaruhi kualitas perolehan hasil belajar siswa antara lain : (1)Intelegensi, (2) Sikap (3) bakat, (4) minat, dan (5) motivasi.

2. Faktor eksternal anak, meliputi:

a. Faktor lingkungan social, seperti para guru, sifat para guru, staf adminitrasi dan teman-teman sekelas.

b. Faktor lingkungan non-sosial, seperti sarana dan prasarana sekolah/belajar, letaknya rumah tempat tinggal keluarga, keadaan cuaca dan waktu belajar yang digunakan anak.

c. Faktor pendekatan belajar, yaitu cara guru mengajar guru, maupun metode, model dan media pembelajaran yang digunakan

Maka dapat disimpulkan bahwa faktor-faktor yang mempengaruhi hasil belajar siswa meliputi faktor intern dan ekstern.Untuk mengoptimalkan hasil belajar maka diperlukan dukungan dari kedua faktor tersebut agar menghasilkan hasil belajar yang baik.

\section{Definisi Contextual Teaching and Learning}

Pembelajaran Kontekstual merupakan suatu konsepsi yang membantu guru mengaitkan isi materi dengan keadaan dunia nyata. Selain itu juga memotivasi siswa untuk menghubungkan pengetahuan-pengetahuan yang diperoleh dan penerapannya dalam kehidupan siswa sebagai anggota keluarga, sebagai warga masyarakat dan sebagai tenaga kerja nantinya. "Contextual Teaching and Learning adalah konsep mengajar dan belajar yang membantu guru menghubungkan materi dengan situasi nyata agar menghubungkan pengetahuan dan terapannya dengan kehidupan sehari-hari sebagai anggota keluarga dan masyarakat" Johnson (2009:65). Definisi ringkas tetapi padat menyatakan bahwa Contextual Teaching and Learning adalah proses belajar mengajar yang erat dengan pengalaman nyata.

Definisi lain menyatakan bahwa Contextual Teaching and Learning adalah pembelajaran yang harus situation and content-specific dan memberi kesempatan dilakukannya pemecahan masalah secara riil/otentik serta latihan dan melakukan tugas. Dari ketiga definisi yang dikutip tersebut dapat dirasakan adanya konsepkonsep sama yang melandasinya. Sedangkan dari referensi yang ada dalam bahasa Inggris Contextual Teaching and Learning mempunyai banyak padanan istilah. Contextual Teaching and Learning dapat juga disebut experiencial learning, real 
world education, active learning, learner centered, intruction, dan learning-incontext. Tentu saja istilah-istilah tersebut mengandung perbedaan-perbedaan penekanan. Sedangkan Sanjaya (2006) mengungkapkan:

Contextual Teaching and Learning adalah suatu strategi belajar mengajar yang menekankan kepada proses keterlibatan siswa secara penuh untuk dapat menemukan materi yang dipelajari dan menghubungkannya dengan situasi kehidupan nyata sehingga mendorong siswa untuk dapat menerapkan dalam kehidupan mereka.

Menurut Bandono (2009), pendekatan kontekstual, pembelajaran yang efektif meliputi:

1. Konstruktivisme, konsep ini yang menuntut siswa untuk menyusun dan membangun makna atas pengalaman baru yang didasarkan pada pengetahuan tersebut.

2. Tanya jawab, dalam hal ini kegiatan tanya jawab yang dilakukan baik guru maupun oleh siswa, pertanyaan guru digunakan untuk memberikan kesempatan kepada siswa untuk berfikir secara kritis dan mengevaluasi cara berfikir siswa, sedangkan pertanyaan siswa merupakan wujud keingintahuan.

3. Inkuiri, merupakan siklus proses dalam membangun pengetahuan/konsep yang bermula dari melakukan observasi, bertanya, investigasi, analisis, kemudian membangun teori atau konsep.

4. Komunitas belajar, adalah kelompok belajar atau komunitas yang berfungsi sebagai wadah komunikasi untuk berbagai pengalaman dan gagasan.

5. Pemodelan, dalam konsep ini kegiatan mendemontrasikan suatu kinerja agar siswa dapat mencontoh, belajar atau melakukan sesuatu sesuai dengan model yang diberikan.

6. Refleksi, yaitu melihat kembali atau merespon suatu kejadian, kegiatan dan pengalaman yang bertujuan untuk mengidentifikasi hal yang sudah diketahui, dan hal yang belum diketahui agar dapat dilakukan suatu tindakan penyempurnaan.

7. Penilaian otentik, prosedur penilaian yang menunjukkan kemampuan (pengetahuan, ketrampilan sikap) siswa secara nyata.

\section{Kerangka Pemikiran}

Belajar merupakan salah satu faktor yang mempengaruhi dan berperan penting dalam pembentukan pribadi dan perilaku individu, dalam kegiatan seharihari. Dalam suatu pembelajaran seorang guru pasti menginginkan peserta didiknya memperoleh capaian hasil belajar yang tinngi. Hasil belajar merupakan hasil dari proses pembelajaran yang di dapat setelah dilakukan evaluasi. .Ada dua faktor utama yang mempengaruhi hasil belajar yaitu karakteristik siswa yang meliputi kemampuan, minat, hasil belajar sebelumnya, motivasi dan karakter pengajaran yang meliputi guru dan fasilitas belajar.Faktor-faktor tersebut merupakan satu kesatuan yang tidak terpisahkan karena guru dan siswa adalah satu kesatuan dalam pembelajaran dikelas dimana metode, strategi pembelajaran, sarana dan sistem administrasi adalah faktor pendukung yang akan membuat sebuah pembelajaran menjadi aktif dan kondusif. 
Salah satu faktor eksternal yang mempengaruhi belajar yaitu strategi pembelajaran yang digunakan oleh guru, didalamnya tercakup model pembelajaran. Model pembelajaran merupakan kerangka konseptual dalam proses pembelajaran dari awal sampai akhir pembelajaran. Dengan penggunaan model pembelajaran siswa dalam proses belajar mengajar menjadi pusatnya (student centered) bukan lagi guru sebagai pusat pembelajaran ( Teaching centered). Ada beberapa model pembalajaran yang dapat meningkatkan hasil belajar siswa. Salah satu model pembelajaran yang dapat meningkatkan hasil belajar siswa yaitu model pembelajaran Contekstual Teaching Learning (CTL).

Contextual Teaching and Learning(CTL) merupakan sebuah sistem belajar yang didasarkan pada filosofi bahwa siswa mampu menyerap pelajaran apabila mereka menangkap makna dari materi akademis dan dapat mengaitkannya dengan pengetahuan dan pengalaman yang sudah mereka miliki sebeumnya.

Pembelajaran kontekstual mendorong siswa agar dapat menemukan hubungan antara materi yang dipelajari dengan situasi kehidupan nyata. Salah satu dampak dari penerapan pembelajaran kontekstual menurut Johnson adalah mencapai standar yang tinggi. Maka dari itu, dengan diterapkankannya model pembelajaran kontekstual ini diharapkan dapat meningkatkan hasil belajar siswa.

Berdasarkan pemaparan di atas diketahui bahwa penggunaan model Contextual Teaching Learning (CTL) memiliki pengaruh terhadap hasil belajar siswa. Adapun hipotesis yang diajukan dalam penelitian ini "Terdapat perbedaan hasil belajar antara siswa kelas eksperimen yang menerapkan model pembelajaran contextual teaching and learning dengan menggunakan media modul, dengan hasil belajar siswa kelas kontrol yang tidak menerapkan model pembelajaran contextual teaching and learning dengan menggunakan media modul”.

\section{METODE DAN PENDEKATAN PENELITIAN}

Dalam penelitian ini, peneliti membagi subjek yang diteliti menjadi dua kelompok yaitu kelompok eksperimen adalah siswa yang diberikan perlakuan (treatment) dengan menerapkan model pembelajaran contextual teaching and learning dengan menggunakan modul pada saat pembelajaran akuntansi berlangsung, sementara kelompok kontrol adalah siswa yang tidak menggunakan model pembelajaran contextual teaching and learning dengan menggunakan modul.Desain penelitian yang digunakan adalah Control-Group Design yang digambarkan sebagai berikut :

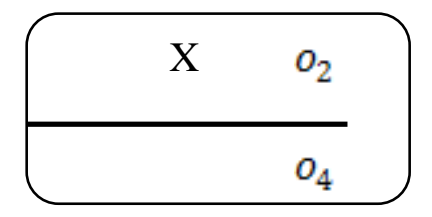

\section{Gambar 1 \\ Desain Eksperimen \\ (Sugiyono $2012: 79$ )}

Keterangan:

$\mathrm{X}$ : perlakuan (treatment)

$\mathrm{O}_{2}$ : post tes kelompok eksperimen 


$$
o_{4}: \text { post tes kelompok control }
$$

\section{Analisis Data dan Pengujian Hipotesis}

\section{Uji Normalitas}

Uji normalitas adalah untuk melihat apakah nilai residual terdistribusi normal atau tidak. Pengujian diadakan dengan maksud untuk melihat normal atau tidaknya sebaran data yang akan dianalisis. Dalam menguji normalitas data sampel yang diperoleh dapat menggunakan uji Chi-Kuadrat. Uji Hipotesis

Setelah melakukan uji normalitas, maka dapat dihitung kebenaran hipotesis dari penelitian ini dengan menggunakan uji-t sebagai berikut :

$$
\mathrm{t}=\frac{\overline{\mathrm{x}}_{1}-\overline{\mathrm{X}}_{2}}{\mathrm{~s} \sqrt{\frac{1}{\mathrm{n}_{1}}+\frac{1}{n_{2}}}}
$$

Dimana :

$$
\begin{aligned}
& \mathrm{S}=\sqrt{\frac{\left(\mathrm{n}_{1}-1\right) \sigma_{1}{ }^{2}+\left(\mathrm{n}_{2}-1\right) \sigma_{2}{ }^{2}}{\left(\mathrm{n}_{1}+\mathrm{n}_{2}\right)-2}} \\
& \text { Dengan : } \quad \frac{\mathrm{t}}{\mathrm{x}_{1}}=\text { uji } \mathrm{t} \\
& \overline{\mathrm{X}}_{1}=\text { nilai rata-rata kelas eksperimen } \\
& \overline{\mathrm{X}}_{2} \quad=\text { nilai rata-rata kelas kontrol } \\
& \mathrm{s} \quad=\text { standar deviasi gabungan } \\
& \mathrm{n}_{1} \quad=\text { banyaknya data kelas eksperimen } \\
& \mathrm{n}_{2} \quad=\text { banyaknya data kelas kontrol } \\
& \sigma_{1}=\text { Standar deviasi kelas eksperimen } \\
& \sigma_{2} \quad=\text { Standar deviasi kelas kontrol }
\end{aligned}
$$

Selanjutnya, nilai $\mathrm{t}$ hitung dibandingkan dengan $\mathrm{t}$ tabel pada $\alpha=0,05$ dan $\mathrm{dk}(\mathrm{n}-2)$ dengan kriteria sebagai berikut :

- Jika $\mathrm{t}_{\text {hitung }} \leq \mathrm{t}_{\text {tabel}}$, maka hipotesis $\mathrm{H}_{\mathrm{o}}$ diterima, $\mathrm{H}_{\mathrm{a}}$ ditolak

- Jika $\mathrm{t}_{\text {hitung }} \geq \mathrm{t}_{\text {tabel}}$, maka hipotesis $\mathrm{H}_{\mathrm{o}}$ ditolak, $\mathrm{H}_{\mathrm{a}}$ diterima.

Hipotesis statistik dalam penelitian ini adalah :

(Sumber: Sudjana:2004)

- $\mathrm{H}_{\mathrm{o}}: \mu 1=\mu 2=$ tidak terdapat perbedaan hasil belajar antara siswa kelas eksperimen yang menerapkan model pembelajaran contextual teaching and learning dengan menggunakan media modul, dengan hasil belajar siswa kelas kontrol yang tidak menerapkan model pembelajaran contextual teaching and learning dengan menggunakan media modul.

- $\mathrm{H}_{a}: \mu 1 \neq \mu 2=$ terdapat perbedaan hasil belajar antara siswa kelas eksperimen yang menerapkan model pembelajaran contextual teaching and learning dengan menggunakan media modul, dengan hasil belajar siswa kelas kontrol yang tidak menerapkan model pembelajaran contextual teaching and learning dengan menggunakan media modul.

\section{Perbedaan Hasil Belajar Kelas Kontrol dan Kelas Eksperimen}

Dengan adanya perbedaan penerapan model pembelajaran pada kelas kontrol dan kelas eskperimen, maka peneliti melakukan analisis terhadap hasil belajar yang dicapai oleh kedua kelas tersebut. Berikut merupakan tabel rekapitulasi nilai postest pada kelas kontrol dan kelas eskperimen: 
Tabel 2

\begin{tabular}{|c|c|c|c|}
\hline \multicolumn{4}{|c|}{ Rekapitulasi Nilai Postest Kelas Kontrol dan Kelas Eksperimen } \\
\hline Nama Sekolah & Kelas Kontrol & Kelas Eksperimen & Perbedaan \\
\hline SMA N 26 & 87 & 89 & 2 \\
\hline SMA N 2 & 76,04 & 86,77 & 10,73 \\
\hline SMA N 24 & 85,17 & 92,94 & 7,77 \\
\hline SMA N 15 & 62,74 & 79,26 & 16,52 \\
\hline SMA N 8 & 82 & 92 & 10 \\
\hline SMA N 19 & 75,66 & 84 & 8,34 \\
\hline SMA N 11 & 84,70 & 92,25 & 7,55 \\
\hline SMA N 14 & 74,97 & 89,46 & 14,49 \\
\hline SMA N 10 & 72 & 84 & 12 \\
\hline SMA N 13 & 67,45 & 70,78 & 3,33 \\
\hline
\end{tabular}

Berdasarkan tabel di atas dapat dideskripsikan bahwa hasil belajar siswa kelompok eksperimen dan kelompok kontrol berbeda, siswa pada kelompok eksperimen memperoleh nilai rata-rata yang lebih tinggi dibandingkan dengan nilai rata-rata yang didapatkan oleh kelompok kontrol.

\section{Pengujian Hipotesis \\ Uji Normalitas}

Sebelum dilakukannya pengujian hipotesis terlebih dahulu dilakukan uji normalitas data. Uji normalitas dilakukan untuk mengetahui apakah data yang diambil berdistribusi normal atau tidak. Uji normalitas dalam penelitian ini dihitung dengan menggunakan uji Chi-Kuadrat $\left(\chi^{2}\right)$. Kriteria keputusan untuk pengambilan keputusan didasarkan pada kriteria sebagai berikut:

- Jika $\chi_{\text {hitung }}^{2}>\chi_{\text {tabel }}^{2}$ artinya data berdistribusi tidak normal

- Jika $\chi_{\text {hitung }}^{2} \leq \chi_{\text {tabel }}^{2}$ artinya data berdistribusi normal

Setelah dilakukan uji normalitas dengan menggunakan Chi-Kuadrat $\left(\chi^{2}\right)$ maka akan didapat hasil apakah data berdistribusi normal atau berdistribusi tidak normal. Jika data tersebut berdistribusi normal maka dilanjutkan pada pengujian hipotesis dengan menggunakan uji hipotesis statistik parametrik yaitu menggunakan uji t. Sementara jika data tidak berdistribusi normal maka pengujian hipotesis tidak menggunakan statistik parametrik melainkan denganmenggunakan statistik non parametrik. Dalam penelitian ini jika ternyata data tidak berdistribusi normal maka pengujian statistik non parametriknya menggunakan uji Wilcoxon.

\section{Pengujian Hipotesis}

Pengujian hipotesis bertujuan untuk menguji apakah hipotesis dalam penelitian ini diterima atau tidak. Hipotesis dalam penelitian ini adalah "Terdapat perbedaan hasil belajar antara kelas yang menerapkan model Contextual Teaching and Learning (CTL) dengan kelas yang tidak menerapkan model Contextual Teaching and Learning (CTL)". Sebelum melakukan pengujian hipotesis maka terlebih dahulu dilakukan perumusan hipotesis penelitian menjadi hipotesis statistik sebagai berikut:

$H_{0}: \mu A=\mu B \rightarrow$ Tidak terdapat perbedaan hasil belajar antara kelas yang menerapkan model Contextual Teaching and Learning (CTL) 
dengan kelas yang tidak menerapkan model Contextual Teaching and Learning (CTL).

$H_{1}: \mu A \neq \mu B \rightarrow$ Terdapat perbedaan hasil belajar antara kelas yang menerapkan model Contextual Teaching and Learning (CTL) dengan kelas yang tidak menerapkan model Contextual Teaching and Learning (CTL).

\section{HASIL DAN PEMBAHASAN}

Berikut merupakan ringkasan hasil uji normalitas dan uji hipotesis:

Tabel 3

RESUME HASIL PENGUJIAN HIPOTESIS

\begin{tabular}{|c|c|c|c|c|c|}
\hline No & Nama Sekolah & Kelas & $\begin{array}{c}\text { Distribusi } \\
\text { Data }\end{array}$ & $\begin{array}{c}\text { Pengujian } \\
\text { Hipotesis }\end{array}$ & Keputusan \\
\hline \multirow{2}{*}{1} & \multirow{2}{*}{$\begin{array}{l}\text { SMA Negeri } \\
26 \text { Bandung }\end{array}$} & Eksperimen & $\begin{array}{c}\text { Tidak } \\
\text { Normal }\end{array}$ & \multirow{2}{*}{$\begin{array}{c}\text { Uji } \\
\text { Wilcoxon }\end{array}$} & \multirow{2}{*}{$\begin{array}{c}\text { Tidak } \\
\text { Terdapat } \\
\text { Perbedaan }\end{array}$} \\
\hline & & Kontrol & $\begin{array}{c}\text { Tidak } \\
\text { Normal }\end{array}$ & & \\
\hline \multirow{2}{*}{2} & \multirow{2}{*}{$\begin{array}{c}\text { SMA Negeri } 2 \\
\text { Bandung }\end{array}$} & Eksperimen & $\begin{array}{c}\text { Tidak } \\
\text { Normal }\end{array}$ & \multirow{2}{*}{$\begin{array}{c}\text { Uji } \\
\text { Wilcoxon }\end{array}$} & \multirow{2}{*}{$\begin{array}{l}\text { Terdapat } \\
\text { Perbedaan }\end{array}$} \\
\hline & & Kontrol & $\begin{array}{c}\text { Tidak } \\
\text { Normal }\end{array}$ & & \\
\hline \multirow{2}{*}{3} & \multirow{2}{*}{$\begin{array}{l}\text { SMA Negeri } \\
24 \text { Bandung }\end{array}$} & Eksperimen & $\begin{array}{c}\text { Tidak } \\
\text { Normal }\end{array}$ & \multirow{2}{*}{$\begin{array}{c}\text { Uji } \\
\text { Wilcoxon }\end{array}$} & \multirow{2}{*}{$\begin{array}{l}\text { Terdapat } \\
\text { Perbedaan }\end{array}$} \\
\hline & & Kontrol & $\begin{array}{c}\text { Tidak } \\
\text { Normal }\end{array}$ & & \\
\hline \multirow{2}{*}{4} & \multirow{2}{*}{$\begin{array}{l}\text { SMA Negeri } \\
15 \text { Bandung }\end{array}$} & Eksperimen & $\begin{array}{c}\text { Tidak } \\
\text { Normal }\end{array}$ & \multirow{2}{*}{$\begin{array}{c}\text { Uji } \\
\text { Wilcoxon }\end{array}$} & \multirow{2}{*}{$\begin{array}{l}\text { Terdapat } \\
\text { Perbedaan }\end{array}$} \\
\hline & & Kontrol & $\begin{array}{c}\text { Tidak } \\
\text { Normal }\end{array}$ & & \\
\hline \multirow{2}{*}{5} & \multirow{2}{*}{$\begin{array}{c}\text { SMA Negeri } 8 \\
\text { Bandung }\end{array}$} & Eksperimen & $\begin{array}{c}\text { Tidak } \\
\text { Normal }\end{array}$ & \multirow{2}{*}{$\begin{array}{c}\text { Uji } \\
\text { Wilcoxon }\end{array}$} & \multirow{2}{*}{$\begin{array}{l}\text { Terdapat } \\
\text { Perbedaan }\end{array}$} \\
\hline & & Kontrol & $\begin{array}{c}\text { Tidak } \\
\text { Normal }\end{array}$ & & \\
\hline \multirow[t]{2}{*}{6} & \multirow{2}{*}{$\begin{array}{l}\text { SMA Negeri } \\
19 \text { Bandung }\end{array}$} & Eksperimen & $\begin{array}{c}\text { Tidak } \\
\text { Normal }\end{array}$ & \multirow{2}{*}{$\begin{array}{c}\text { Uji } \\
\text { Wilcoxon }\end{array}$} & \multirow{2}{*}{$\begin{array}{l}\text { Terdapat } \\
\text { Perbedaan }\end{array}$} \\
\hline & & Kontrol & Normal & & \\
\hline \multirow[t]{2}{*}{7} & \multirow{2}{*}{$\begin{array}{l}\text { SMA Negeri } \\
11 \text { Bandung }\end{array}$} & Eksperimen & $\begin{array}{c}\text { Tidak } \\
\text { Normal }\end{array}$ & \multirow{2}{*}{$\begin{array}{c}\text { Uji } \\
\text { Wilcoxon }\end{array}$} & \multirow{2}{*}{$\begin{array}{l}\text { Terdapat } \\
\text { Perbedaan }\end{array}$} \\
\hline & & Kontrol & Normal & & \\
\hline \multirow{2}{*}{8} & \multirow{2}{*}{$\begin{array}{l}\text { SMA Negeri } \\
14 \text { Bandung }\end{array}$} & Eksperimen & Normal & \multirow{2}{*}{ Uji T } & \multirow{2}{*}{$\begin{array}{l}\text { Terdapat } \\
\text { Perbedaan }\end{array}$} \\
\hline & & Kontrol & Normal & & \\
\hline \multirow{2}{*}{9} & \multirow{2}{*}{$\begin{array}{l}\text { SMA Negeri } \\
13 \text { Bandung }\end{array}$} & Eksperimen & Normal & \multirow{2}{*}{ Uji T } & \multirow{2}{*}{$\begin{array}{c}\text { Tidak } \\
\text { Terdapat } \\
\text { Perbedaan }\end{array}$} \\
\hline & & Kontrol & Normal & & \\
\hline 10 & SMA Negeri & Eksperimen & Tidak & Uji & Terdapat \\
\hline
\end{tabular}




\begin{tabular}{lcccc}
\hline \multirow{2}{*}{10 Bandung } & & Normal & Wilcoxon & Perbedaan \\
\cline { 2 - 3 } & Kontrol & Normal & \\
\hline
\end{tabular}

Pada tabel 3 terlihat dari 10 sekolah yang menjadi tempat eksperimen ada 8 yang terdapat perbedaan hasil belajar antara kelas yang menerapkan model Contextual Teaching and Learning (CTL) dengan menggunakan media modul dengan kelas yang tidak menerapkan model Contextual Teaching and Learning (CTL) dengan menggunakan media modul. Pemberian perlakuan pada 8 sekolah memiliki perbedaan dan perlakuan tersebut sangat berarti dalam meningkatkan hasil belajar. Sementara pada 2 sekolah yang lainnya yakni SMAN 26 dan SMAN 13 perlakuan tidak berarti, artinya mau menggunakan atau pun tidak menggunakan model contectual dengan menggunakan modul hasil belajar siswa sama.

Pada hakikatnya model pembelajaran merupakan salah satu faktor yang mempengaruhi prestasi belajar siswa termasuk pada mata pelajaran Akuntansi. Model pembelajaran ialah pola yang digunakan sebagai pedoman dalam merencanakan pembelajaran di kelas. Model pembelajaran perlu dipahami guru agar dapat melaksanakan pembelajaran secara efektif dalam meningkatkan prestasi pembelajaran. Dalam penerapannya, model pembelajaran harus dilakukan sesuai dengan kebutuhan siswa karena masing-masing model pembelajaran memiliki tujuan, prinsip, dan sasaran yang berbeda-beda.

Mata pelajaran akuntansi merupakan salah satu mata pelajaran yang dipelajari di SMA. Pokok bahasan yang diajarkan dalam mata pelajaran akuntansi di SMA meliputi siklus akuntansi pada perusahaan jasa dan siklus akuntansi pada perusahaan dagang. Materi akuntansi merupakan materi pelajaran yang bersifat prosedural yang mengharuskan siswa memahami materi dasar untuk melanjutkan ke materi berikutnya dan menuntut siswa dapat memahami setiap tahapan materi yang dipelajari secara tuntas, namun beberapa materi sering dianggap sulit oleh siswa, sehingga siswa kesulitan untuk melanjutkan ke materi berikutnya dan mengakibatkan rendahnya hasil belajar siswa. Salah satu materi yang dianggap sulit oleh siswa dalam pokok bahasan siklus akuntansi pada perusahan dagang adalah materi jurnal khusus. Padahal materi jurnal khusus merupakan materi dasar atau materi awal yang dipelajari dalam siklus akuntansi perusahan dagang, jika siswa tidak memahami materi jurnal khusus, maka siswa akan kesulitan untuk melanjutkan materi berikutnya.

Ketika suatu materi dianggap sulit oleh sebagian besar siswa maka guru sudah seharusnya berpikir cara terbaik apa yang harus dilakukan agar materi bisa dipahami oleh siswa. Model pembelajaran merupakan faktor yang sangat penting dalam proses pembelajaran di sekolah. Guru harus memiliki kemampuan dan keterampilan untuk dapat memilih model pembelajaran yang tepat dan sesuai dengan meteri pelajaran, potensi siswa dan tujuan pembelajaran yang diharapkan, karena dengan penggunaan model pembelajaran yang tepat dapat memudahkan siswa memahami materi yang dipelajari, siswa dapat mencapai tujuan pembelajaran yang diharapkan dan mencapai hasil belajar yang optimal.

Model Contextual Teaching and Learning (CTL) merupakan model pembelajaran yang membantu guru mengaitkan antara materi yang diajarkan dengan situasi nyata siswa sebagai anggota keluarga dan masyarakat. Melalui model Contextual Teaching and Learning (CTL) pembelajaran dikaitkan dengan 
sehidupan sehari-hari siswa yang mampu membawa perubahan ke arah yang lebih baik, lebih membuat siswa aktif dan tidak mengharuskan siswa menghafal konsep-konsep, tetapi lebih mendorong siswa untuk membangun sendiri pengetahuannya melalui interaksi dengan objek, pengetahuan awal yang mereka miliki, pengalaman dan lingkungan siswa.

Penggunaan model Contextual Teaching and Learning (CTL) dapat digunakan dalam membantu siswa memahami materi jurnal khusus dengan bantuan alat peraga berupa dokumen atau bukti transaksi seperti yang sering siswa temukan pada kehidupan sehari-harinya, sehingga siswa lebih mudah dalam memahami materi jurnal khusus tersebut. Sehingga dapat meningkatkan hasil belajar siswa pada mata pelajaran akuntansi. Dengan batuan dokumen atau bukti transaksi siswa langsung mengalami bahwa dalam kehidupannya nyata bukan soal narasi yang mereka dapatkan tetapi sekumpulan dukumen sebagai bukti dari sebuah transaksi yang telah dilakukan yang kemudian harus dilakukan pencatatan.

Pada penelitian ini, model Contextual Teaching and Learning (CTL) diterapkan pada kelas eksperimen yaitu kelas XII IPS. Guru menerapkan model Contextual Teaching and Learning (CTL) dengan menggunakan media modul dalam pembelajaran akuntansi pokok bahasan siklus akuntansi perusahaan dagang dan pada materi pencatatan transaksi ke dalam jurnal khusus. Penerapan model Contextual Teaching and Learning (CTL) dengan menggunakan media modul dilaksanakan selama dua kali pertemuan pembelajaran. Setelah model Contextual Teaching and Learning (CTL) dengan menggunakan modul diterapkan, maka pada pertemuan kedua diakhiri dengan dilakukannya post tes untuk mengukur hasil belajar siswa dan untuk melihat apakah penerapan model Contextual Teaching and Learning (CTL) dengan menggunakan media modul dapat membantu siswa dalam meningkatkan hasil belajarnya, maka peneliti membandingkan apakah terdapat perbedaan hasil belajar antara kelas eksperimen yang menerapkan model Contextual Teaching and Learning (CTL) dengan menggunakan media modul dengan kelas kontrol yang tidak menerapkan model Contextual Teaching and Learning (CTL) dengan menggunakan media modul.

Pada kelas kontrol yang tidak menerapkan model Contextual Teaching and Learning (CTL). Guru menjelaskan materi dengan metode ceramah, lalu memberikan beberapa contoh soal dipapan tulis, siswa mendapatkan materi secara langsung dari guru. Setelah guru menjelaskan materi dan memberikan contoh soal, siswa diberikan latihan soal mengenai materi yang dijelaskan oleh guru, yaitu siswa ditugaskan untuk mengerjakan soal yang ada pada LKS (Lembar Kerja Siswa) yang dimiliki oleh siswa, kemudian siswa secara individu mengerjakan soal tersebut. Setelah siswa selesai mengerjakan soal latihan, guru selanjutnya memeriksa hasil pekerjaan siswa. Siswa menerima informasi dari guru tanpa harus mencari informasi mengenai materi yang dipelajari dan tidak menganilisis secara mandiri materi yang dipelajari tersebut. Hal ini membuat siswa kurang aktif dalam proses pembelajaran dan siswa pun kurang termotivasi untuk mengikuti proses pembelajaran akuntansi dengan baik. Keadaan tersebut mengakibatkan siswa kurang memahami materi yang sudah diberikan oleh guru, sehingga menyebabkan rendahnya hasil belajar yang diperoleh siswa.

Berbeda dengan kelas kontrol, pada kelas eksperimen guru menerapkan model Contextual Teaching and Learning (CTL), dalam proses pembelajaran dikelas eksperimen guru melaksanakan tujuh komponen dari model Contextual 
Teaching and Learning (CTL), ketujuh komponen tersebut adalah kontruktivisme (Contructivism), bertanya (Quesitioning), menemukan (Inquiri), masyarakat belajar (Learning Community), permodelan (Modeling), refleksi (Reflection) dan penilaian sebenarnya (Authentic Assessment).

Dengan menggunakan model pembelajaran ini, dan melaksanakan tujuh komponen yang sudah ditetapkan pada model Contextual Teaching and Learning (CTL), siswa mendapatkan pengalaman belajar yang berbeda, dimana siswa dituntut untuk mencari informasi secara mandiri baik itu dengan pengalaman, media belajar lain, atau bertanya kepada teman dan guru, siswa dilibatkan secara aktif untuk menemukan makna dari materi yang dipelajari dengan cara menghubungkannya pada kehidupan nyata siswa. Kegiatan tersebut dibantu dengan menggunakan alat peraga berupa dokumen atau bukti transaksi pada perusahan dagang seperti yang sering siswa temukan pada kehidupan sehariharinya.

Model Contextual Teaching and Learning (CTL) ini membuat siswa terpacu untuk lebih aktif dalam pembelajaran akuntansi, hal ini terlihat pada meningkatnya aktivitas siswa, dimana siswa lebih banyak bertanya kepada teman dan guru mengenai materi yang belum dipahaminya, dan siswa yang sudah paham dapat menjawab pertanyaan dari guru dan temannya, selain itu siswa lebih termotivasi untuk mengikuti proses pembelajaran akuntansi dengan baik. Hal tersebut dapat dilihat dari antusias siswa dalam mengerjakan soal latihan yang diberikan oleh guru dan mempresentasikan jawaban dari soal yang telah mereka kerjakan secara berkelompok didepan kelas. Keadaan tersebut membuat siswa dapat lebih mudah memahami materi pelajaran akuntansi yang sedang mereka pelajari.

Dalam arti luas model Contextual Teaching and Learning (CTL) menekankan pada proses keterlibatan siswa untuk menemukan makna dari materi yang diajarkan dengan adanya pengalaman yang didapatkan oleh siswa secara langsung, sehingga pembelajaran lebih bermakna bagi siswa. Proses belajar dengan menggunakan model Contextual Teaching and Learning (CTL) tidak mengharapkan siswa hanya menerima pelajaran, tetapi proses mencari dan menemukan sendiri materi pelajaran. Selain itu, siswa didorong untuk dapat menemukan hubungan antara materi yang dipelajari dengan kehidupan nyata siswa, dan materi yang dipelajari tidak hanya sebatas dipahami atau hanya disimpan dalam otak kemudian dilupakan, tetapi sebagai bekal mereka dalam menjalani kehidupan nyata siswa dimasa depan.

Pada proses belajar dengan menggunakan model Contextual Teaching and Learning (CTL) juga siswa dituntut untuk dapat menghargai perbedaan setiap individu dan dapat bekerja sama dalam suatu kelompok untuk dapat memecahkan masalah yang dihadapi. Hal tersebut dapat menjadi pembelajaran untuk siswa dalam menjalani kehidupan siswa kelak didalam dunia kerja dan didalam masyarakat.

Proses belajar dengan menggunakan model kontekstual tidak mengharapkan siswa hanya menerima pelajaran, tetapi proses mencari dan menemukan sendiri materi pelajaran. Dalam pembelajaran kontekstual siswa didorong untuk dapat menemukan hubungan antara materi yang dipelajari dengan kehidupan nyata siswa, dan materi yang dipelajari tidak hanya sebatas dipahami atau hanya 
disimpan dalam otak kemudian dilupakan, tetapi sebagai bekal mereka dalam mengarungi kehidupan nyata di masa depan.

Proses belajar mengajar yang sangat dianjurkan ialah siswa diberikan kesempatan untuk mendapatkan pengalaman langsung, agar pembelajaran lebih bermakna bagi siswa. Hal ini lah yang mendasari model pembelajaran kontekstual. Pada model pembelajaran ini siswa dilibatkan secara aktif untuk menemukan makna dari materi yang dipelajari dengan cara menghubungkan pada kehidupan nyata siswa. Dalam arti luas pembelajaran kontekstual yang menekankan pada proses keterlibatan siswa untuk menemukan makna dari materi yang diajarkan dengan adanya pengalaman yang didapatkan oleh siswa.

Setelah menerapkan model Contextual Teaching and Learning (CTL) dengan menggunakan media modul selama dua kali pertemuan, dan diakhiri dengan dilaksanakan post test. Guru memberikan soal post test yang sama untuk membandingkan perbedaan hasil belajar pada kelas eksperimen dengan hasil belajar pada kelas kontrol. Soal post test yang diberikan berupa dokomen atau bukti transaksi pada perusahaan dagang. Sebelum dilakukannya pengujian hipotesis, terlebih dahulu peneliti melakukan uji normalitas data. Uji normalitas dilakukan untuk mengetahui apakah data yang diambil berdistribusi normal atau tidak. Uji normalitas dalam penelitian ini dihitung dengan menggunakan uji ChiKuadrat $\left(\chi^{2}\right)$, setelah dilakukan uji normalitas maka didapatkan bahwa ada 8 sekolah kedua data yaitu data post test kelas kontrol dan kelas eksperimen berdistribusi tidak normal. Sehingga proses selanjutnya dalam pengujian hipotesis dapat menggunakan perhitungan statistika non parametrik, yaitu menggunakan wilcoxon tuntuk melihat perbedaan pada data. Sementara 2 sekolah kedua data yaitu data post test kelas kontrol dan kelas eksperimen berdistribusi normal. Sehingga proses selanjutnya dalam pengujian hipotesis dapat menggunakan perhitungan statistika parametrik, yaitu menggunakan uji $\mathrm{t}$ tuntuk melihat perbedaan pada data

Selanjutnya dilakukan pengujian data menggunakan uji wilcoxon untuk sekolah yang memiliki data berdistribusi tidak normal yaitu SMA N 26 didapatkan bahwa $Z_{\text {hitung }}-0898>$ nilai $Z_{\text {tabel }} 1,96$ sehingga $H_{0}$ diterima dan $H_{1}$ ditolak. Dengan demikian berarti tidak terdapat perbedaan hasil belajar antara kelas yang menerapkan model Contextual Teaching and Learning (CTL) dengan kelas yang tidak menerapkan model Contextual Teaching and Learning (CTL).

SMAN 2 didapatkan bahwa $Z_{\text {hitung }} 2,910>$ nilai $Z_{\text {tabel }} 1,96$ sehingga $H_{0}$ ditolak dan $H_{1}$ diterima. Dengan demikian berarti terdapat perbedaan hasil belajar antara kelas yang menerapkan model Contextual Teaching and Learning (CTL) dengan kelas yang tidak menerapkan model Contextual Teaching and Learning (CTL).

SMAN 24 didapatkan bahwa $Z_{\text {hitung }} 3,187>$ nilai $Z_{\text {tabel }} 1,96$ sehingga $H_{0}$ ditolak dan $H_{1}$ diterima. Dengan demikian berarti terdapat perbedaan hasil belajar antara kelas yang menerapkan model Contextual Teaching and Learning (CTL) dengan kelas yang tidak menerapkan model Contextual Teaching and Learning (CTL).

SMAN 1 didapatkan bahwa $Z_{\text {hitung }} 3,784>$ nilai $t Z_{\text {tabel }} 1,96$ sehingga $H_{0}$ ditolak dan $H_{1}$ diterima. Dengan demikian berarti terdapat perbedaan hasil belajar antara kelas yang menerapkan model Contextual Teaching and Learning (CTL) 
dengan kelas yang tidak menerapkan model Contextual Teaching and Learning (CTL).

SMAN 15 didapatkan bahwa $Z_{\text {hitung }} 2,052>$ nilai $t Z_{\text {tabel }} 1,96$ sehingga $H_{0}$ ditolak dan $H_{1}$ diterima. Dengan demikian berarti terdapat perbedaan hasil belajar antara kelas yang menerapkan model Contextual Teaching and Learning (CTL) dengan kelas yang tidak menerapkan model Contextual Teaching and Learning (CTL).

SMAN 19 didapatkan bahwa $Z_{\text {hitung }} 9,023>$ nilai $t Z_{\text {tabel }} 1,96$ sehingga $H_{0}$ ditolak dan $H_{1}$ diterima. Dengan demikian berarti terdapat perbedaan hasil belajar antara kelas yang menerapkan model Contextual Teaching and Learning (CTL) dengan kelas yang tidak menerapkan model Contextual Teaching and Learning (CTL).

SMAN 11 didapatkan bahwa $Z_{\text {hitung }} 3,142>$ nilai $Z_{\text {tabel }} 1,96$ sehingga $H_{0}$ ditolak dan $H_{1}$ diterima. Dengan demikian berarti terdapat perbedaan hasil belajar antara kelas yang menerapkan model Contextual Teaching and Learning (CTL) dengan kelas yang tidak menerapkan model Contextual Teaching and Learning (CTL).

SMAN 10 didapatkan bahwa $Z_{\text {hitung }} 2,050>$ nilai $Z_{\text {tabel }} 1,96$ sehingga $H_{0}$ ditolak dan $H_{1}$ diterima. Dengan demikian berarti terdapat perbedaan hasil belajar antara kelas yang menerapkan model Contextual Teaching and Learning (CTL) dengan kelas yang tidak menerapkan model Contextual Teaching and Learning (CTL).

Sementara untuk 2 SMA yaitu SMA N 13 dan SMA N 14 memiliki data berdistribusi normai sehingga dilakukan uji hipotesis dengan menggunakan uji t. Untuk SMA N 13 didapatkan bahwa $t_{\text {hitung }} 1,226>$ nilai $t_{\text {tabel }} 1.664$ sehingga $H_{0}$ diterima dan $H_{1}$ ditolak. Dengan demikian berarti tidak terdapat perbedaan hasil belajar antara kelas yang menerapkan model Contextual Teaching and Learning (CTL) dengan kelas yang tidak menerapkan model Contextual Teaching and Learning (CTL).

SMA N 14 didapatkan bahwa $t_{\text {hitung }} 5,811>$ nilai $t_{\text {tabel }} 1,992$ sehingga $H_{0}$ ditolak dan $H_{1}$ diterima. Dengan demikian berarti terdapat perbedaan hasil belajar antara kelas yang menerapkan model Contextual Teaching and Learning (CTL) dengan kelas yang tidak menerapkan model Contextual Teaching and Learning (CTL).

Melihat hasil eksperimen dan uji hipotesis dari 10 sekolah $20 \%$ tidak ada perbedaan artinya di 2 sekolah tersebut yaitu SMA N 26 dan SMA N 13 penggunaan model ini tidak berpengaruh terhadap peningkatan hasil belajar siswa. Tetapi $80 \%$ dari hasil eksperimen dan ji hipotesis terjadi peningkatam hasi belajar. Dengan demikian Model pembelajaran kontekstual dengan menggunakan media modul sangat efektif untuk meningkatkan hasil belajar siswa sesuai dengan teori yang dikemukakan oleh Johnson bahwa "CTL membantu para siswa menemukan makna dalam pelajaran mereka dengan cara menghubungkan materi akademik dengan konteks kehidupan keseharian. Mereka membuat hubungan-hubungan penting yang menghasilkan makna dalam melaksanakan pembelajaran yang diatur sendiri, bekerja sama, berpikir kritis dan kreatif, menghargai orang lain, mencapai standar yang tinggi, dan berperan serta dalam tugas-tugas penilaian autentik". Salah satu dampak dari penerapan pembelajaran kontekstual menurut Johnson 
adalah mencapai standar yang tinggi. Mencaai standar yang tinggi dalam arttian meningkatkan hasil belajar sebagaimana tujuan akhir dari proses pembelajaran.Lebih lanjut Johnson menuturkan bahwa mencapai standar yang tinggi adalah mendorong siswa cara untuk mencapai keberhasilan dalam belajar dan mendorong siswa untuk mencapai yang terbaik dalam mengembangkan bakat dan minatnya.

Hasil penelitian ini sesuai dengan penelitian sebelumnya diantaranya Lingga Bayu Segara dalam penelitiannya yang berjudul "pengaruh model pembelajaran kontekstual berbasis hands on activity terhadap prestasi belajar siswa" menyatakan bahwa penerapan model pembelajaran kontekstual berbasis hands on activity berpengaruh terhadap prestasi belajar siswa. Penelitian yang dilakukan oleh Rensi Yulizah tentang model pembelajaran kontekstual dengan judul "pengaruh model pembelajaran kontekstual terhadap hasil belajar siswa" menyimpulkan bahwa dengan diterapkannya model pembelajaran kontekstual berpengaruh terhadap peningkatan hasil belajar siswa. Dan juga penelitian dede azis dengan judul Pengaruh model contextual teaching learning berpengaruh terhadap hasil belajar, dari hasil penelitiannya menyatakan bahwa penerapan model pembelajaran kontekstual berpengaruh terhadap hasil belajar siswa.

Oleh karena itu, proses pembelajaran dengan menerapkan model Contextual Teaching and Learning (CTL) dapat membuat siswa dapat lebih mudah memahami materi pelajaran termasuk pada mata pelajaran akuntansi, karena model Contextual Teaching and Learning (CTL) ini membuat meteri pelajaran akuntansi yang dianggap abstrak oleh siswa menjadi lebih konkrit karena dihubungkan dengan kehidupan nyata siswa. Keadaan tersebut membantu meningkatkan hasil belajar siswa, sehingga menyebabkan adanya perbedaan hasil belajar yang dicapai siswa, dimana hasil belajar siswa kelas eksperimen lebih unggul dibandingkan hasil belajar siswa kelas kontrol.

Dengan demikian, model Contextual Teaching and Learning (CTL) yang diterapkan pada kelompok eksperimen ini berpangaruh pada hasil belajar siswa, sehingga model Contextual Teaching and Learning (CTL) ini efektif jika diterapkan pada mata pelajaran akuntansi, khususnya pada kompetensi dasar mencatat transaksi atau bukti transaksi ke dalam jurnal khusus.

\section{KESIMPULAN DAN REKOMENDASI \\ Kesimpulan}

Berdasarkan hasil penelitian yang telah dilakukan di SMA Negeri di kota Bandung, maka dapat disimpulkan bahwa Terdapat perbedaan hasil belajar siswa kelas XII yang menerapkan model pembelajaran contextual teeaching and learning dengan menggunakan media modul antara hasil belajar siswa kelas XII yang tidak menerapkan model contextual teaching and leaning. Artinya dengan terdapat perbedaan maka penerapan model pembelajaran contextual teaching and learning memiliki pengaruh terhadap hasil belajar. Maka dengan adanya pengaruh penerapan model pembelajaran contextual teaching and learning tersebut dapat disimpulkan bahwa penerapan model pembelajaran contextual teaching and learning dengan menggunakan media modul dapat dijadikan sebagai suatu stategi untuk meningkatkan hasil belajar. 


\section{Rekomendasi}

Berdasarkan hasil penelitian dan kesimpulan di atas, maka terdapat beberapa rekomendasi dari peneliti sebagai berikut :

1. Bagi Guru, berdasarkan hasil penelitian dapat terlihat bahwa penerapan model contextual teaching and learning dengan menggunakan media modul dapat meningkatkan hasil belajar siswa, maka dari itu, guru diharapkan dapat menerapkan model pembelajaran contextual teaching and learning dengan menggunakan media modul secara efektif agar tujuan pembelajaran dapat tercapai.

2. Bagi Peneliti Selanjutnya, peneliti selanjutnya dapat mengembangkan penelitian mengenai model contextual teaching and learning pada sekolah lain untuk dijadikan pembanding dengan hasil penelitian ini. Selain itu peneliti selanjutnya juga diharapkan melakukan penelitian sejenis dengan lebih memperhatikan instrumen penelitian yang akan digunakan dan pelaksanaan waktu penelitian yang perlu disesuaikan dengan kegiatan yang dilaksanakan oleh pihak sekolah.

\section{DAFTAR PUSTAKA}

Djamarah, S B.(2002). Psikologi Belajar. Jakarta: Rineka Cipta

Sardiman A.M. (2008). Interaksi dan Motivasi Belajar Mengajar. Jakarta: PT.Raja Grafindo Persada.

Elaine B. Johnson (2009) Contextual Teaching and Learning. Bandung MLC

Sugiyono. (2012). Metode Penelitian Pendidikan, pendekatan kuantitatif, kualitatif, dan R.D. Bandung: Alfabeta.

Syah M. (2006). Psikologi Pendidikan dengan Pendekatan Baru. Bandung : Remaja Rosda Karya.

Slameto. (2003). Belajar dan Faktor-Faktor yang Mempengaruhinya. Jakarta: Rineka Cipta.

Sanjaya W (2006) Stategi Pembelajaran Berorientasi Standar Proses Pendidikan. Jakarta Kencana Prenada Media.

Sudjana. (2004). Statistika untuk Ekonomi dan Niaga II. Bandung: Tarsito 